\title{
Four Domains of Public Value Creation: A Core Typology
}

\author{
Dr Kate Joyner \\ Graduate School of Business, Queensland University of Technology, Brisbane, Australia
}

\begin{abstract}
The public management literature has failed to capture the arenas of operation of the public sector manager in one holistic framework, thus inhibiting the development of a more complete theory of leadership that drives public value. This paper develops a core typology of arenas of public value creation, based on the locus of interaction (internal or external to the government organisation) and the public value purpose (trading or policy development). Four arenas are described, illustrating that public sector managers in complex policy areas traverse all forms of institutional structure includingmarket, hierarchy and hybrid. The typology developed and discussed is an attempt to provide more precision in characterising the nature of policy leadership. Building on the public value work of Moore $(1995 ; 2013$; 2014),the typology enables theorising on the role and nature of leadership in driving public value.
\end{abstract}

Keywords: Delivery public value; service delivery in government; public governance in complexity; policy leadership; the systems manager in government; policy collaboration.

\section{Introduction}

"At a practical level, public value aims must be achievable. Public managers must know how to mobilise their resources to create, organize and operate a market to meet the declared objectives. This may require the public manager to be both persuasive in making the case for mobilising the resources of partner agencies, and expert in regulating the performance of contracted bodies." (Moore, 2014, p 9)

Moore usefully links the concept of the achievability of public value aims with the leadership skill of the public manager, which he also calls the strategic 'system' manager. Also useful is highlighting that different skills are required to mobilise resources in different arenas of operation and value creation. That is, while working in the shared power environment of a policy partnership may require the system manager to be skilled in the arts of influence and persuasion, achieving ends with contracted bodies to deliver specified services requires the ability to apply the 'harder' skills of enforcing performance clauses or regulating.

A senior manager with responsibility for developing a policy response to the shortage of safe and affordable housing, for example, will find herself asan agent within a public value system, managing the performance of her own direct reports, coordinating or 'harmonising' policy initiatives with other areas across government, managing design and construct contracts for housing stock, and working as part of cross-sectoral policy networks.

While the public sector leadership literature has long identified that achieving outcomes requires the public manager to be skilled in working across boundaries (Williams, 2002), frameworks are required which allow an analysis of how leadership skills, practices and mindsets need to adjust according to the dynamics of the different arenas in which the systems manager must operate. This paper argues that the literature needs to transcend the NPM focus of efficiency and the NPG focus on leading through plurality to view the terrain of the policy manager from a systems perspective.

This paper proposes a core typology of value creation arenas in the public sector to enable this form of analysis. The typology explicates four arenas from identifying the locus of the interaction as internal or external and the purpose of the public value creation as trading or policy collaboration. In so doing, the paper aims to extend the public value work of Mark Moore $(1995,2013)$ by exploring further the concept of public value 'achievability' or operational capability by further examination of requisite leadership skills and capability as one of its core factors.

International Journal of Operations Management, vol. 1, issue 4, pp. 24-32, July 2021 


\section{Institutional Structures and Typologies in Organizational Theory: A literature Review}

Typologies, as multidimensional classifications of entities (Blau and Scott, 1962), serve the purpose in theory development of generating analytical tools to stimulate thinking (Mills and Margulies, 1980) and hypothesis generation.

This paper seeks to provide a classification of the arenas of production of a system manager in the public sector, delivering public value outcomes in complex policy areas. As such, it builds on previous typological work in organisational theory extending from the seminal work of Coase (1991) with his concept of 'institutional structures of production' and Williamson's (1985) work which systematised market, hierarchy and hybrid forms for securing transactions, with hybrids being those 'middle kind' of institutional structures, neither market nor hierarchy, such as supply-chain clusters, networks, relational contracts and cooperatives.

Menard (2004) sought to provide a theoretical underpinning for the hybrid, providing a classification structure around what had previously been thought to be a heterogeneous collection of forms lacking the regularity for theorising. Menard (2004, p351) observes that (hybrids) "rely on partners who maintain distinct property rights and remain independent residual claimants" and classified the field on the different mechanisms adopted to manage issues arising from pooling resources, contracting and competing. He notes that in organising activities to produce rents through interfirm coordination and cooperation, the risk of opportunism is always present, and tensions can emerge from how rents are divided. Hybrid forms have added complexity in coordinating tasks, information and decisions across often multiple organisational boundaries. It follows that key decisions arising are choice of partners, governance arrangements for coordination across firms and developing adequate information systems to ensure information symmetry (Menard, 2004).

Alliances, defined by Gulati (1998) as "voluntary arrangements between firms involvingexchange, sharing, or codevelopment of products, technologies, or services" are a variety of the hybrid form, and thus give rise to these distinctive challenges. However, alliance themselves take many forms from tightly structured and controlled equity joint ventures to loose arrangements for coordination and sharing. Theory development has benefitted from the typological work of Grandori and Soda (1995), who distinguished ten organisational coordination mechanisms to sustaining and regulating inter-firm cooperation. Similarly, Gulati (1998) typified alliances structures on tight-loose principles according to how much they shared equity and employed hierarchical forms of control.

Helpful for this paper is the work of Rangan and Yoshino (1996), whose typology has the purpose of supporting managers within alliances. They propose that "an alliance-seeking firm acts in two dimensions, cooperation and competition, which generally play out as cooperation and conflict. Successful alliances optimise along both dimensions" (Rangan and Yoshino, 1996, p7). They distinguish two dimensions: conflict potential and the extent of organisational interaction with a classification of low or high, giving rise to four types, each with their own managerial concerns. They state that "to capture the full potential of alliance-based strategy requires careful and disciplined thinking on the part of a company's senior management. An understanding of the typology of alliances and familiarity with the road map to forging alliances can usefully guide that thinking” (Rangan and Yoshino, 1996, p13).

Organisational theory that has distinguished and classified the structures of market, hierarchy and various hybrids organisational forms and their distinguishing dynamics and tensions has predominantly come from the business sector. The public management literature has addressed the why government has moved away from traditional hierarchies into more inter-organizational forms for policy development and service delivery. Much of the New Public Management literature (Hood, 1991) is concerned with efficiency and examines the move away from hierarchical structures to more market forms of delivery. Osborne (2009), representing the later New Public Governance movement, shifts the focus to more plural, networked forms of delivery and governance of processes rather than contracts.

Studies have examined the risk to the public from the difficulties of integration across multiple contributing organisations (e.g. Kettl, 2001; Rhodes, 1997, 1998). A theme in this conceptual work is a shift away from seeing government in a central controlling position to notions of power-sharing, exploring issues of accountability and fragmentation. 
The attendant managerial challenges of this more plural policy world have been captured by Williams (2002), who characterises the public policy manager as 'boundary spanner.' He typifies types of organisation as modern and postmodern, with their respective concerns as intra and inter-organisational. The modern organisation, he proposes, is structured around bureaucracy and rules and is suited to a skills-based technocratic form of management. The postmodern organisation, by contrast, is characterised by a decision-making framework of negotiation and consensus and is suited to a more relational form of management.

With others in the public management literature, Williams (2002) proposes that complex 'wicked' policy challenges are more suited to forms of organisation and governance that promote collaboration, partnership and networking. They are also more suited to managers who have a relational style designed to build social capital (p106). However, this paper holds that the systems manager conceived by Mark Moore (2014) must marshal resources from several different arenas, traversing market, hierarchy and different varieties and intensities of hybrid organisational structures. In proposing a core typology of these arenas of public sector value creation, the paper is underpinned by a more realist perspective. While collaborative and partnering approaches are certainly part of the repertoire of a systems manager, they have perhaps been overemphasised in the public management literature. With Rangan and Yoshino (1996) the paper argues that the extent to which public sector system managers understand the distinguishing features of each part of the terrain, its inherent dynamics and tensions, and practice the disciplined thinking and ability to adjust styles accordingly, represents the organisational capability to achieve public value ends.

\section{Four Areanas of Public Value Creation: A Core Typology}

The example provided in the introduction has our system manager working across four arenas to deliver outcomes in the complex policy arena of social housing. These four can be mapped across two analytical dimensions, which arise when examining where and why our system managers 'marshal resources' (Moore, 2014) to achieve public value ends.

These resources are found both internally, with the government's technology, knowledge, employees and budget, and also externally, leveraging the capabilities of suppliers and partners from across different levels of government and in different sectors. Thus, the typology identifies the locus of interaction as the first dimension.

The system manager also marshals resources for different value-creating purposes. She oversees the delivery of public services, both programmed (BAU) and project related. The manager also seeks to develop policy, both through coordinating internally and integrating with other levels of government and across sectors. The second dimension of the typology is then public value purpose. These two dimensions and the four arenas are presented in Figure One. 
Figure 1: Arenas of Public Value Creation: Typology

\begin{tabular}{|l|l|}
\hline Service delivery by employed staff & $\begin{array}{l}\text { Policy coordination with intra- } \\
\text { government partners }\end{array}$ \\
\hline $\begin{array}{l}\text { Service Delivery through third party } \\
\text { suppliers }\end{array}$ & $\begin{array}{l}\text { Policy integration with different levels } \\
\text { of government, community groups, } \\
\text { NGOs, universities and the private } \\
\text { sector }\end{array}$ \\
\hline
\end{tabular}

Trading

Policy Integration

Public Value Purpose

In the top left is the internal service delivery arena, which is the focus of much organisational theory. Using the example of our system manager in social housing, in this arena the manager will be managing her own staff employed by the government department to deliver agreed policy outputs as specified in their role descriptions and governed by the legitimate authority of the manager as provided by the organisation, as well as more broadly by industrial agreements and law. As characterised in Table One below, the manager in this arena will largely have a logic of efficiency and productivity, managing the performance of staff against agreed indicators. As the organisational and leadership literature suggests, high performance may be achieved through a range of styles and practices, but in general, the requirement of the leader in this arena will be the setting of direction and encouraging staff to follow.

The external service delivery arena, in the bottom left quadrant, are contracts with third party suppliers. Service delivery may be governed by traditional 'hard dollar' contracts, or relational contracts, which are a more flexible framework based on social norms and jointly defined objectives. In our example, our social housing system manager may have gone to the market for the design and construction of units of social housing stock. Her concern as a manager and as contract principal, would be to ensure value through the procurement process and then to achieve value through monitoring the achievement of agreed delivery milestones and managing contractual risk. If a traditional contract, failure to deliver can be managed through enforcing contractual provision through commercial and legal means. If a relational contract, her first escalation would be to a joint governance board: power relations here being equal. However, the dynamic of principal and contractor remains in both forms.

The internal policy coordination arena, in the top right quadrant, requires the systems manager to marshal resources by working toward initiatives that align or 'join-up' (Bellamy and Raab, 2005) complementary policy areas inside government. Complex policy ends are held to require inter-dependent approaches, achieved by reducing fragmentation of effort, ensuring all actors in a system can share knowledge, information and resources, and thereby contribute to more efficient and effective implementation and service delivery (Mulgan, 2005). As Table One suggests, these processes are achieved through cross-cutting governance mechanisms such as intra-government Steering Groups and Committees, as well as more informally by information-sharing networks. However, the challenges of these whole-ofgovernment efforts are well documented (e.g. Bakvis and Juillet, 2004), with cultures of protection and risk aversion within government departments arising from vertical reporting and reward structures (Bakvis, 2002). Our system manager in this arena loses immediate control over the ability to design and achieve policy outcomes, as power bases are many and varied across the policy arena (Kingdon, 1995). Her concern will be to work toward consensus on key policy and strategy initiatives that will form a common platform for joint action. Authoritarian or top-down leadership 
approaches will not be effective in this arena: our system manager must draw from the repertoire of alliance-building, developing social and relational capital to marshal when critical for acting on windows of policy opportunity (Kingdon, 1995).

In our final arena (bottom right), our system manager is working toward policy integration among multiple actors to contribute to policy solutions in housing. These actors may include governments at different levels, with different regulatory powers over where, for example, budgets for housing are directed (Federal governments) and where social housing can be constructed (local government). She may be working with universities for policy research, and with the housing development industry to leverage private sector investment in social housing. She may be working with the community sector to provide support services to residents of social housing. Increasingly, our system manager will be called on to work directly with interest groups from the broader community of potential users of social housing. We privilege the idea of citizen's outcome preferences and co-design (Halligan, Buick, and O'Flynn, 2011). In this interorganisational arena, power relationships and interests are even more decentralised and diffuse than in our policy coordination intra-government arena.

Here the mechanism is governance rather than government. As Stoker (1998) defines, governance refers to the "development of governing styles in which boundaries between and within public and private sectors have become blurred. The essence of governance is its focus on governing mechanisms which do not rest on recourse to the authority and sanctions of government. It's an interaction of a multiplicity of governing and each other influencing actors" (Stoker, 1998: 17). Formal mechanisms which might be implemented include Memoranda of Understanding, Deeds of Cooperation or social sanction as a member of a policy network.

Our system manager may employ several practices for strategising and decision making in fragmented, plural environments (Denis, Langley and Rouleau, 2007), and like a diplomat in the geopolitical arena, work to find where there are a natural confluence of interests and therefore policy opportunities. The metaphor of the diplomat is also useful as an indicator of leadership style in this arena: it will be facilitative and relational, rather than the directive style accepted in more unitary contexts (Williams, 2002).

Table 1: Characterising the Four Arenas of Public Value Creation 
Dr Kate Joyner

Graduate School of Business, Queensland University of Technology, Brisbane, Australia

\begin{tabular}{|l|l|l|l|l|}
\hline & $\begin{array}{l}\text { Internal Service } \\
\text { Delivery }\end{array}$ & $\begin{array}{l}\text { External Service } \\
\text { Delivery }\end{array}$ & $\begin{array}{l}\text { Internal Policy } \\
\text { Coordination }\end{array}$ & $\begin{array}{l}\text { External Policy } \\
\text { Integration }\end{array}$ \\
\hline $\begin{array}{l}\text { Institutional } \\
\text { Structure }\end{array}$ & Hierarchy & $\begin{array}{l}\text { Market/Hybrid } \\
\text { (where relational } \\
\text { contract) }\end{array}$ & Hierarchy/Hybrid & $\begin{array}{l}\text { Non- } \\
\text { hierarchical } \\
\text { /Hybrid }\end{array}$ \\
\hline $\begin{array}{l}\text { Mavernance } \\
\text { Concerns }\end{array}$ & $\begin{array}{l}\text { Industrial } \\
\text { employment } \\
\text { arrangements } \\
\text { Hierarchical } \\
\text { authority }\end{array}$ & $\begin{array}{l}\text { Traditional and } \\
\text { Relational } \\
\text { Contracts }\end{array}$ & $\begin{array}{l}\text { 'Joined-up } \\
\text { Government' } \\
\text { Steering Groups } \\
\text { and Committee }\end{array}$ & $\begin{array}{l}\text { MOUs, Deeds } \\
\text { of Cooperation, } \\
\text { and Network } \\
\text { Governance }\end{array}$ \\
& $\begin{array}{l}\text { Efficiency and } \\
\text { productivity }\end{array}$ & $\begin{array}{l}\text { Contractual } \\
\text { performance; } \\
\text { Sanaging risk. } \\
\text { Trust building } \\
\text { (where relational } \\
\text { contract) }\end{array}$ & $\begin{array}{l}\text { Achieving } \\
\text { consensus from } \\
\text { organisational } \\
\text { interests and } \\
\text { power bases }\end{array}$ & $\begin{array}{l}\text { Strategising and } \\
\text { decision making } \\
\text { in fragmented, } \\
\text { pluralistic } \\
\text { environments }\end{array}$ \\
\hline Leadership style & $\begin{array}{l}\text { Sets Direction } \\
\text { Evokes } \\
\text { followership }\end{array}$ & $\begin{array}{l}\text { Enforces and } \\
\text { monitors } \\
\text { negotiates and } \\
\text { regulates }\end{array}$ & $\begin{array}{l}\text { Relational, } \\
\text { building support } \\
\text { alliances }\end{array}$ & $\begin{array}{l}\text { Diplomatic, } \\
\text { facilitative and } \\
\text { relational }\end{array}$ \\
\hline
\end{tabular}

\section{Typology as Public Value System: Discussion}

In mapping the terrain of the public policy manager, the typology is not intended to suggest four discrete and separate arenas. The social housing manager used as an illustration for this paper would certainly not see her world in that way. Rather the paper proposes that the four arena model be seen as an attempt at bounding a system of operation in which our public policy manager is a purposeful agent. As Moore (2014) would have it, the mission of the public manager, or strategic 'system' manager, is to mobilise their resources to 'create, organise and operate a market to meet the declared objectives' (p7). The question for our manager, as part of a public value system, is how and from where these resources can best be leveraged and what wider implications these choices may have. For a particular set of public value objectives, will hierarchical (in-house) approaches be best? Is there a mature market for a commercial, outsourced approach? Will we require the concerted efforts of partner organisations from a range of sectors? Will I need to achieve common ground on policy from across the government? In choosing an approach, how will this affect the social housing system as a whole?

In viewing the four arenas as a system, there is also the opportunity to see the leadership challenge as systems thinking. As Table One identifies, the four arenas encompass the different institutional structures of hierarchy, market and hybrid, each with distinct dynamics and leadership challenges. As systems theorists Snowden and Boone (2007) would suggest, the adept leader knows how to identify their context and to change their behaviour to match. They encourage leaders to identify problems as simple, (clear and known cause and effect relationships) complicated, (requiring technical expertise) complex, (a situation in constant flux, requiring more experimentation) and chaotic (where no manageable patterns exist). They observe that many leaders lead effectively, but usually in only a few domains, and rarely prepare themselves or their organisations for diverse or 'unordered' contexts (para 32). By explicitly identifying the range of arenas of operation of the public systems manager, the typology foregrounds the need for capability across all problem types and to be adaptive across the whole system. 
Leadership adaptiveness is also framed by Heifetz, Grashow and Linsky (2009). As with the model of Snowden and Boone (2007), adaptive leaders can recognise the nature of the problem and whether this is technical, with known tools and frameworks for resolution, or whether they are faced with an adaptive challenge, one with legitimate but competing perspectives, and where there must be deep stakeholder engagement to find a way forward. Adaptive challenges are often those termed 'wicked problems' in public policy language, systems problems with no ready answers.

Our conception of leadership for public value therefore transcends the NPM (Hood, 1991) thinking of efficiency in service delivery through monitoring of market contracts. It also transcends New Public Governance (Osborne, 2006) with its emphasis on the hybrid world of decentred governance and leading through pluralism and networks. The approach in this paper, as set out in the four arena typology, is both-and: the systems manager must traverse and be effective in both market and hierarchical structures, and additionally must be adept in what Williams (2002) calls 'postmodern' leadership to be effective in a range of hybrid arrangements to achieve policy goals.

\section{Contribution to Theory and Practice}

Theoretically, the typology is intended to make three contributions. Firstly, by identifying the two dimensions of locus of intervention and public value purpose, the typology can become the analytical tool that may stimulate further research propositions about how and where public value can best be created, creating some variables and a common language. Secondly, by delineating the four arenas as a system, the paper invites more systemic views of public value creation, extending the current focus on the 'wicked policy problems.' Thirdly, the paper seeks to extend the conception of operational capability of Mark Moore (1995) to bring leadership capability, particularly the adaptive leadership capacity of public sector leaders, into the calculus of the achievability of public policy outcomes. A focus on the operational capability dimension may stimulate more directed research into the nature of leadership for public value creation.

In practice, the public value work of Mark Moore (1995) has met with a strong reception in the public sector, forming the basis of many leadership development programs. The four arenas model is intended to provide an additional thinking-frame to add to this work. The paper also invites further attention tosystems thinking and adaptive leadership (Heifetz, Grashow and Linsky2009) as models to guide the public leader.

\section{Conclusion}

This paper proposed and discussed a four-arena typology of public value creation. Our two dimensions are the locus of interaction (internal or external to the public sector organisation) and public value purpose (trading or policy coordination and integration). These dimensions give rise to four arenas: Service delivery by employed staff, service delivery by third party suppliers, policy coordination with intra-government partners, and policy integration with crossgovernment and cross-sectoral stakeholders and partners. Each domain is characterised according to its underpinning institutional structure (market, hierarchy or hybrid), its governance mechanisms, managerial concerns, and the leadership style most suited to achieving ends. By capturing these elements in one construct, the paper enables the development of complete theorising of leadership which drives public value.

The public sector literature has evolved from emphasis on hierarchy through the Public Administration paradigm, to emphasising efficiency through New Public Management,and current emphasis through New Public Governance on leading in horizontal, dispersed power and pluralist network arrangements. This paper argues that each paradigm remains relevant and has value. Still, each is partial in achieving a full understanding of the role and challenges of the public systems manager. By seeing the whole system in one view,theories of leadership for public value can embrace holism.

The typology and discussion presented attempts to order and extend this important area of leadership development practice and research. 


\section{References}

- Bakvis, H.\& Juillet, L. (2004). The Horizontal Challenge: Line Departments, Central Agencies and Leadership. Ottawa: Canada School for Public Service.

- Bakvis, H. (2002). Pulling Against Gravity? Horizontal Management in the Canadian Federal Government. In M. Considine (ed) Knowledge, Networks and Joined-Up Government, IPSA Research Committee Proceedings, Centre for Public Policy, Melbourne, 57-75.

- Bellamy, C.\&Raab, C. (2005). Joined-up government and privacy in the United Kingdom: managing tensions between data protection and social policy. Part II, Public Administration, 83, 2, 393-415 Crossref

- $\quad$ Blau, P. M. \& Scott, W. R. (1962) Formal organizations. Chandler. San Francisco.

- Coase, R. (2014). The Institutional Structure of Production. Journal des Économistes et des Études Humaines, 2(4), pp. 431-440. Crossref

- Denis, J.-L., Langley, A., \& Rouleau, L. (2007). Strategizing in pluralistic contexts: Rethinking theoretical frames. Human Relations, 60(1) 179-217. Crossref

- Grandori, A., \& Soda, G. (1995). Inter-firm networks: Antecedents, mechanisms and forms. Organization Studies, 16(2), 183-214. Crossref

- Gulati, R. (1998). Alliances and networks. Strategic Management Journal, 19, 293-317. Crossref

- Halligan, J. Buick, F. \&O'Flynn, J. (2011). Experiments with Joined-Up, Horizontal and Whole-ofGovernment in Anglophone Countries in A. Massey (ed.), International Handbook on Civil Service Systems, Edward Elgar, Cheltenham. Crossref

- Heifetz, R, Grashow, A \& Linsky, M. (2009). The Practice of Adaptive Leadership: Tools and Tactics for Changing Your Organization and the World. Boston: Harvard Business Press

- Hood, C. (1991). Public management for all seasons. Public Administration, 69, 3-19. Crossref

- Kettl, D. (2000). The transformation of governance: Globalization, devolution and the role of government. Public Administration and Review, 60(6), 488-497. Crossref

- Kingdon, J. W. (1995). Agendas, alternatives, and public policies (2nd ed.). New York: Harper Collins College Publishers.

- Ménard, C. (2004). The Economics of Hybrid Organizations. Journal of Institutional and Theoretical Economics JITE160(3): 345-376. Crossref

- Mills, P. K., \& Margulies, N. (1980). Toward a core typology of service organizations. Academy of Management Review, 5: 255-265. Crossref

- Moore, M. (1995). Creating Public Value: Strategic Management in Government. Cambridge: Harvard University Press.

- Moore, M.H. (2013). Recognizing public value. Cambridge: Harvard University Press Crossref

- Moore, M. (2014) Creating public value: Transforming Australia's Public Service. EY Working Paper.

- Mulgan, G. (2005). Joined-Up Government: Past, Present, and Future. Joined-Up Government. : British Academy Online. Retrieved 1 Jul. 2018, from http://britishacademy.universitypressscholarship.com/view/10.5871/bacad/9780197263334.001.0001/ upso-9780197263334-chapter-8 Crossref

- Osborne, S. P. (2009). The new public governance: Emerging perspectives on the theory and practice of public governance. Milton Park, Oxon: Routledge. Crossref

- Rangan, U. \&Yoshino, M., (1996). Forging alliances: A guide to top management.Columbia Journal of World Business 31 (3), 6-13. Crossref

- $\quad$ Rhodes, R. A. W. (1997). From marketization to diplomacy: It's the mix that matters. Public Policy and Administration, 12, 31-50. Crossref

- $\quad$ Rhodes, R. A. W. (1998). Different roads to unfamiliar places: UK experience in comparative perspective. Australian Journal of Public Administration, 57(4), 19-31. Crossref

- Snowden, D. J. \& Boone, M. E. (2007). A Leader's Framework for Decision Making. Harvard Business Review, 85(11), 68-76

- Stoker, G. (1998). Governance as theory: five propositions. International Social Science Journal, No. 155: 17-28. Crossref 
- Williams, P. (2002). The competent boundary spanner. Public Administration, 80(1), 103.

Williamson, O.E. (1985). The Economic Institutions of Capitalism: The Free Press-Macmillan: New York. $\underline{\text { Crossref }}$ 